\title{
Nematicidal activity of crambe extracts on Meloidogyne spp.
}

\section{Atividade nematicida de extratos de crambe sobre Meloidogyne spp.}

\author{
Sidiane Coltro-Roncato ${ }^{1 *}$; José Renato Stangarlin²; Affonso Celso Gonçalves Jr. ${ }^{3}$; \\ Odair José Kuhn²; Edilaine Della Valentina Gonçalves"; \\ Omari Dangelo Forlin Dildey ${ }^{1}$; Éder Lisandro de Moraes Flores ${ }^{4}$
}

\begin{abstract}
Alternative methods for the control of nematodes, such as the use of plant secondary metabolites, can be explored for integrated pest management systems. The objective of this work was to assess the best solvent for obtaining allyl isothiocyanate from Crambe abyssinica leaves, and the effects of this extract on Meloidogyne incognita and M. javanica. Dry leaves of C. abyssinica at $200 \mathrm{mg} \mathrm{L}^{-1}$ were used to prepare extracts by using water (by infusion and grinding), acetone, water + ethanol (hydroalcoholic extraction), methanol, hexane, and chloroform as solvents. Following the evaporation of the solvents, the residue was resuspended in water for use in the experiments. Distilled water and chemical nematicide were used as control treatments. Once the most effective extracts were defined, the following dosages of dried crambe leaves were used: 0, 200,300, 400, and $500 \mathrm{mg} \mathrm{L}^{-1}$. High performance liquid chromatography (HPLC) was used to quantify the allyl isothiocyanate present in the extracts. After the solvents evaporated, the residues were eluted with water and used in assays with 200 eggs for the hatching test or 200 second stage juveniles (J2) for mobility and mortality tests. The hydroalcoholic extract was the most effective in reducing the hatching of $M$. incognita and $M$. javanica juveniles, by 71.6 and 74.4 percentage points, respectively. The mortality of $M$. incognita and M. javanica in the hydroalcoholic extract was 93.2 and $64.4 \%$, respectively, followed by the methanol extract (17.6 and $34 \%$ ) and the extract obtained by grinding (9.2 and 28\%). The hydroalcoholic extract at $250 \mathrm{mg} \mathrm{L}^{-1}$ showed high nematicidal effect. The HPLC analysis of the extracts revealed that only the methanol and hydroalcoholic extracts had allyl isothiocyanate, indicating that the inhibitory effects on the hatching, mobility, and mortality were not solely attributed to the presence of this compound.
\end{abstract}

Key words: Allyl isothiocyanate. Alternative control. Crambe abyssinica. Glucosinolate. Meloidogyne incognita. Meloidogyne javanica.

\section{Resumo}

Medidas alternativas de controle de fitonematoides, como o uso de metabólitos secundários produzidos pelas plantas, podem ser exploradas no contexto do manejo integrado em fitossanidade. O objetivo deste trabalho foi verificar quais os melhores solventes para obtenção de alil isotiocianato de folhas de Crambe abyssinica, e o efeito dos mesmos sobre Meloidogyne incognita e Meloidogyne javanica.

\footnotetext{
${ }^{1}$ Discentes do Curso de Doutorado, Programa de Pós-graduação em Produção Vegetal, Laboratório de Nematologia, Departamento de Agronomia, Universidade Estadual do Oeste do Paraná, UNIOESTE, Campus Marechal Cândido Rondon, PR, Brasil. E-mail: sidianecoltro@gmail.com; edilainevalentina@gmail.com; omaridildey@hotmail.com

2 Profs. Drs., Departamento de Agronomia, Fitopatologia, UNIOESTE, Campus Marechal Cândido Rondon, PR, Brasil. E-mail: jose.stangarlin@unioeste.br; ojkuhn@gmail.com

3 Prof. Dr., Departamento de Agronomia, Química Agrícola e Ambiental, UNIOESTE, Campus Marechal Cândido Rondon, PR, Brasil. E-mail: affonso133@hotmail.com

4 Prof. Dr., Departamento de Química, Universidade Tecnológica Federal do Paraná, UTFPR, Campus Medianeira, PR, Brasil. E-mail: ederflores@gmail.com

* Author for correspondence
} 
Folhas secas de crambe na concentração de $200 \mathrm{mg} \mathrm{L}^{-1}$ foram utilizadas para o preparo dos extratos com os solventes água (para os extratos obtidos por infusão e trituração), acetona (cetônico), água + álcool etílico (hidroalcoólico), álcool metílico (metanólico), hexano (hexânico) e clorofórmio (clorofórmico). Após a rotoevaporação dos solventes o resíduo foi ressuspenso em água para utilização nos ensaios. Água destilada e nematicida foram usados como tratamentos controle. Após a seleção dos melhores extratos, os selecionados foram avaliados nas seguintes doses: 0, 200, 300, 400 e $500 \mathrm{mg} \mathrm{L}^{-1}$ de folhas secas de crambe. Para quantificar o alil isotiocianato presente nos extratos foi utilizada cromatografia líquida de alta pressão (HPLC). Para avaliar a eclosão foram utilizados 200 ovos e para motilidade e mortalidade, 200 juvenis de segundo estádio (J2). O extrato hidroalcoólico foi o mais efetivo em reduzir a eclosão de juvenis de $M$. incognita e $M$. javanica, com redução de 71.6 e 74.4 pontos percentuais, respectivamente. A mortalidade de $M$. incognita e M. javanica para o extrato hidroalcoólico foi de $93.2 \%$ e $64.4 \%$, respectivamente, seguido do extrato metanólico $(17.6 \%$ e $34 \%)$ e do extrato obtido por trituração $(9.2 \%$ e $28 \%)$, respectivamente. Para o extrato hidroalcoólico, a concentração com melhor efeito nematicida foi de $250 \mathrm{mg} \mathrm{L}^{-1}$. Dos extratos analisados por HPLC, somente o metanólico e o hidroalcoólico apresentaram alil isotiocianato, indicando que os efeitos inibitórios da eclosão, motilidade e mortalidade não foram devidos apenas à presença desse composto.

Palavras-chave: Alil isotiocianato. Controle alternativo. Crambe abyssinica. Glicosinolato. Meloidogyne incognita. Meloidogyne javanica.

\section{Introduction}

Meloidogyne nematodes cause drastic alterations in root development by inducing the formation of giant cells that act as nutrient sources for them. Meloidogyne species are biotrophic parasites (FERRAZ; MONTEIRO, 2011) that cause reduction in crop yields and in the quality of agricultural products, which reflects in losses for producers and in higher prices for consumers. It is estimated that the worldwide production losses caused by Meloidogyne nematodes in 2012 reached 118 billion dollars (ATKINSON et al., 2012). These nematodes have a very broad host range and almost all parasitize crops, increasing the complexity of their control. Even the balanced use of chemicals can have long-term effects, leading to selection of resistant plant pathogens and pollution, resulting in adverse consequences for the environment and society. However, many studies have been conducted in the search for new active ingredients of natural origin, such as plant extracts, which have secondary metabolites with antimicrobial activity or inducing resistance (NEVES et al., 2009; STANGARLIN et al., 2011).

Several plants show a resistance against nematodes and this is attributed to the presence of certain active compounds, such as flavonoids and rosmarinic acid (CABONI et al., 2013), allyl isothiocyanate, acryloyl isothiocyanate, bezyl isothiocyanate (NEVES et al., 2009; WU et al., 2011; AISSANI et al., 2013), azadirachtin, desacetylnimbim, desacetylsalannin, nimbin, and salannin (SILVA et al., 2008).

These plant extracts have shown potential as raw material for the production of natural nematicides, as described by Franzener et al. (2005), Elbadri et al. (2008), and Silva et al. (2008). The nematicidal activity can depend on both the plant used for the preparation of the extract and the solvent used in the extraction (AMARAL et al., 2002).

Plant derived compounds can protect plants against nematodes because of their nematicidal effect, as is the case of glucosinolates present in brassica species. These compounds belong to the secondary metabolism and can act against other plant pathogens (WU et al., 2009). Substances such as isothiocyanates, nitriles, thiocyanates, and epinitriles occur when glucosinate is hydrolyzed by myrosinase, an enzyme connected to the membrane (CLARKE, 2010). The glucosinolates and their hydrolytic products inhibit cell mitosis and cell proliferation. The isothiocyanates are essential for 
cell growth inhibition, since in general, the proteins are the main isothiocyanate binding sites within the cell (JACKSON; SINGLETARY, 2004; MI et al., 2008). The mode of action of allyl isothiocyanate on nematodes has not been fully determined, however, some hypotheses suggest that a mechanism causing oxidative damage to DNA can be induced by allyl isothiocyanate (MURATA et al., 2000).

The crambe plant (Crambe abyssinica Hochst. ex Fries) belongs to the family Brassicaceae. It is an annual plant native to the Mediterranean region, which has high oil content (35\%) and high erucic acid content, used for industrial purposes and biodiesel production (LEONI et al., 1997; DAUBOS et al., 1998; FALASCA et al., 2010). The crambe plant contains glucosinolates, and the dust produced from the plant shows toxicity against plant nematodes (LEONI et al., 1997). However, the efficiency of aqueous extracts of brassica crops in nematode control has not been studied.

The objective of the present study was to identify the best solvents for obtaining extracts from crambe leaves with nematicidal/nematostatic activity against Meloidogyne incognita (Kofoid \& White) Chitwood and M. javanica (Treub) Chitwood, and quantify the presence of allyl isothiocyanate in these extracts.

\section{Material and Methods}

The following three experiments were performed: (1) evaluation of solvent efficiency in extracting nematicide compounds; (2) testing different dosage of the most effective extracts; and (3) quantification of the allyl isothiocyanate.

\section{Experiment 1: Obtaining crambe extracts}

Crambe leaves were collected from a commercial cultivation in the municipality of Cascavel-PR, (latitude 24\%57'21" $\mathrm{S}$ and longitude 53'27'19" $\mathrm{W}$, altitude $781 \mathrm{~m}), 35$ days after emergence. The leaves were dried at $45{ }^{\circ} \mathrm{C}$ for $48 \mathrm{~h}$, and ground to a powder to pass a 48 mesh sieve, using a grinder.

The extracts were prepared at a concentration of $200 \mathrm{mg}$ of crambe powder per liter of solvent. The extracts were prepared as follows: 1) obtained by infusion (water); 2) obtained by grinding (water); 3) acetone extract (NEVES et al., 2009); 4) obtained by hydroalcoholic solution (70\% ethanol and 30\% water) (LOGUERCIO et al., 2005); 5) methanol extract (ELBADRI et al., 2008); 6) hexane extract (ELBADRI et al., 2008); and 7) chloroform extract (COSTA et al., 2004). Extracts were obtained in five replicates. All extracts obtained, excluding the aqueous infusion and grinding, were subjected to a vacuum rotary evaporator at $50{ }^{\circ} \mathrm{C}$ and, following removal of the solvent, were resuspended in 1000 $\mathrm{ml}$ of distilled water. Two controls were used: a negative (distilled water) and a positive [chemical nematicide imidacloprid + thiodicarb $(9.12 \mathrm{~mL}$ $\left.\mathrm{L}^{-1}\right)$ ]. In all treatments (including the negative water control), except for the chemical nematicide treatment, $0.6 \%$ Tween 20 was added to distilled water.

\section{Nematicidal/nematostatic activity}

The effect of different extracts and dosages on the hatching, mobility, and mortality of M. incognita and $M$. javanica was evaluated. The nematodes were obtained from tomato plants, according to Boneti and Ferraz (1981), from a commercial cultivation in the municipality of Marechal Cândido Rondon, PR. Individual females were extracted from the roots and identified based on the perineal region pattern (HARTMAN; SASSER, 1985). Following species identification, pure populations were maintained in tomato plants in a greenhouse.

The effect of extracts on hatching was tested by placing 200 eggs in $5 \mathrm{~mL}$ of extracts. The effect of extracts on the mobility and mortality of nematodes was tested by placing 200 second stage juveniles (J2) in $5 \mathrm{~mL}$ of extracts. Both tests were performed according to the methodology of Costa et al. (2001), 
in sterile plastic bottles with $70 \mathrm{~mL}$ capacity. For the hatching test, the eggs were incubated for 15 days at room temperature, after which the percentage of $\mathrm{J} 2$ hatched was determined. The mobility of $\mathrm{J} 2$ in contact with the crambe extract was evaluated after $24 \mathrm{~h}$, by counting any inactive J2. Subsequently, J2 were transferred to a 400 mesh sieve, and the extract was substituted with water. After $24 \mathrm{~h}$, a second assessment was carried out, and the J2 remaining inactive were considered dead. They were considered inactive and/or dead the aspect of J2 straight or slightly bent. The determination of the number of eggs and $\mathrm{J} 2$ in the sample was performed with the aid of a Peter's blade.

\section{Experiment 2: Dosage of crambe extracts}

From the results of the effects of the different types of extracts, three extracting methods showed a higher nematicide effect (hydroalcoholic, methanol, and grinding). Tests on hatching and mobility/ mortality of nematodes were carried out with varying dosages of the three extracts $(0,200,300$, 400 , and $500 \mathrm{mg} \mathrm{L}^{-1}$ of crambe powder), as well as an additional treatment using a chemical nematicide $\left(500 \mu \mathrm{L}\right.$ Carbofuran $\left.\mathrm{L}^{-1}\right)$. A total of six treatments were tested, with five replicates each.

Experiment 3: Isothiocyanate identification and quantification in crambe extracts

To quantify the allyl isothiocyanate present in all extracts from Experiment 1, reverse phase high performance liquid chromatography (HPLC) was used with a $\mathrm{C} 18$ column. Three replicates were analyzed for each extract. The calibration standard used was allyl isothiocyanate (Sigma-Aldrich), the mobile phase was acetonitrile: Milli-Q water 60:40 (v/v), and the UV detection was at $244 \mathrm{~nm}$ (HERZALLAH; HOLLEY, 2012).

\section{Statistical analysis}

The design used in all three experiments was completely randomized. Analysis of variance was performed with the $F$ test $(p<0.05)$, and the comparison of mean for the first experiment (types of extracts) was performed by the Scott Knott test $(p<0.05)$. For the second experiment (dose), the results were submitted to variance analysis, regression was then used to evaluate dose effect, and the Dunnett test was carried out to compare each dose of the extract with the chemical treatment. For the third experiment (quantification of isothiocyanate), the comparison of means was performed using the Tukey test $(\mathrm{p}<0.05)$. Statistical analysis was carried out using the free Genes software (CRUZ, 2006).

\section{Results and Discussion}

\section{Experiment 1: Effect of crambe extracts}

The hydroalcoholic extract was the most effective in reducing the hatching of $M$. incognita juveniles (Table 1), with only $3.2 \%$ juveniles hatched. Hatching in the infusion and grinding extracts was 48 percentage points lower compared to the water control. The inhibitory effect on juvenile hatching may be because of chemical compounds present in the extracts, which have ovicidal properties and can act as larvicides. Such compounds are alkaloids, flavonoids, saponins, amides, benzamides, and ketones, which alone or in combination, affect embryonic development or cause mortality of embryos, as noted in Chromolaena odorata L. extracts, Azadirachta indica A. Juss., Ricinus communis L., and Cymbopogon citratus D.C. used in M. incognita control (ADEGBITE; ADESIYAN, 2005). 
Table 1. Effect of Crambe abyssinica leave extracts and chemical nematicide (imidacloprid + thiodicarb) on the hatching (\%), mobility (\%), and mortality (\%) of Meloidogyne. incognita juveniles. Marechal Cândido Rondon, PR, 2013.

\begin{tabular}{cccc}
\hline Treatments & $\begin{array}{c}\text { Hatching } \\
\text { of juveniles (\%) }\end{array}$ & $\begin{array}{c}\text { Mobility of Second } \\
\text { Stage Juveniles (\%) }\end{array}$ & $\begin{array}{c}\text { Mortality of Second Stage } \\
\text { Juveniles (\%) }\end{array}$ \\
\hline Infusion & $26.00 \mathrm{e}$ & $26.20 \mathrm{~d}$ & $6.80 \mathrm{c}$ \\
Grinding & $27.20 \mathrm{e}$ & $32.80 \mathrm{c}$ & $9.20 \mathrm{c}$ \\
Methanolic & $50.00 \mathrm{~d}$ & $23.20 \mathrm{~d}$ & $17.60 \mathrm{~b}$ \\
Ketone & $58.00 \mathrm{c}$ & $20.00 \mathrm{~d}$ & $10.00 \mathrm{c}$ \\
Hydroalcoholic & $3.20 \mathrm{~g}$ & $94.80 \mathrm{a}$ & $93.20 \mathrm{a}$ \\
Hexanenic & $62.80 \mathrm{~b}$ & $22.40 \mathrm{~d}$ & $16.00 \mathrm{~b}$ \\
Chloroform & $45.60 \mathrm{~d}$ & $13.60 \mathrm{e}$ & $9.60 \mathrm{c}$ \\
Water & $74.80 \mathrm{a}$ & $11.20 \mathrm{e}$ & $10.00 \mathrm{c}$ \\
Chemical nematicide & $14.80 \mathrm{f}$ & $58.40 \mathrm{~b}$ & $20.00 \mathrm{~b}$ \\
\hline CV (\%) & 11.01 & 10.32 & 15.21 \\
\hline
\end{tabular}

Means followed by the same letter within each column are not significantly different according to the Scott-Knott test at $5 \%$ probability.

There was a high inhibition of $\mathrm{J} 2$ mobility by the hydroalcoholic extract, which was greater than the chemical nematicide treatment, with a difference of 36.4 percentage points. The highest mortality rate was induced by the hydroalcoholic extract, with 75.6 and 77.2 percentage points higher mortality than the methanol and hexane extracts, respectively.

The lowest hatching rate of $M$. javanica juveniles occurred in the hydroalcoholic extract (Table 2), which was 74.4 percentage points lower compared to the water control and approximately 13 percentage points lower compared to the infusion and grinding extracts. The treatment with the hydroalcoholic extract showed a greater inhibition of mobility compared to the other treatments. The mortality of $M$. javanica in the hydroalcoholic extract was 28 and 30.4 percentage points higher than in the chemical nematicide and methanol extract, respectively (Table 2). The ketone, chloroform, and hexane extracts were less efficient in reducing $\mathrm{J} 2$ hatching, since these treatments higher hatching rate when compared to the chemical treatment approximately 22.8, 41.6 and 37.2 percentage points, respectively, and a lower hatching rate $(36.8,18$ and 22.4 percentage points, respectively) when compared to the water control.
The same extracts were not effective in reducing mobility, with approximately 17.6, 18.4, and 16.8 percentage points lower mobility reduction, respectively, compared to the chemical nematicide treatment. The mortality of $\mathrm{J} 2$ in the ketone, chloroform, and hexane extracts was approximately 7.6, 5.6, and 8 percentage points lower compared to the chemical nematicide treatment. A similar trend was observed by Neves et al. (2009), in which the ketone extracts and the garlic chloroform, mustard and pepper, showed no significant reduction in the population of nematodes and the number of galls of $M$. incognita in tomato. According to Silva et al. (2008), the hexane extract of neem seeds was not effective in increasing Heterodera glycines I. J2 mortality, when compared to aqueous and methanolic extracts, and this was explained by the hexane extract's composition which is essentially lipids. The Cinnamomum cassia P. chloroform extract also showed no nematicide effect against the pine nematode Bursaphelenchus xylophilus K. (NGUYEN et al., 2009). The extraction methods have an important effect in obtaining glucosinolates, influencing the amount of substances extracted from vegetables that can have toxic effects on pathogens (MOHN et al., 2007; NEVES et al., 2009; WU et al., 2011). Some solvents have a higher affinity for 
isothiocyanates extraction, which was attributed to existing polarity differences (WU et al., 2009), which may explain the different responses of each solvent on the variables analyzed.

In this experiment, the chemical nematicide was not as efficient as a nematostatic and nematicide, causing low mortality in the assessed nematodes.
The mortality rate of $M$. incognita (20\%) was close to the water control $(10 \%)$, and much lower than the hydroalcoholic extract (93.2\%). The same results were observed in $M$. javanica, to a lesser extent. For both nematodes, the mortality rate when using chemical nematicides was lower than 50\%, demonstrating the necessity of using alternative chemical nematicides for the other tests.

Table 2. Effect of Crambe abyssinica leave extracts and chemical nematicide (imidacloprid + thiodicarb) on the hatching (\%), mobility (\%), and mortality (\%) of Meloidogyne javanica juveniles. Marechal Cândido Rondon, PR, 2013.

\begin{tabular}{cccc}
\hline Treatments & $\begin{array}{c}\text { Hatching } \\
\text { of juveniles (\%) }\end{array}$ & $\begin{array}{c}\text { Mobility of Second Stage } \\
\text { Juveniles (\%) }\end{array}$ & $\begin{array}{c}\text { Mortality of Second Stage } \\
\text { Juveniles (\%) }\end{array}$ \\
\hline Infusion & $14.80 \mathrm{~d}$ & $40.40 \mathrm{~b}$ & $30.00 \mathrm{c}$ \\
Grinding & $15.20 \mathrm{~d}$ & $40.80 \mathrm{~b}$ & $28.00 \mathrm{c}$ \\
Methanolic & $37.20 \mathrm{c}$ & $35.20 \mathrm{c}$ & $34.00 \mathrm{~b}$ \\
Ketone & $39.20 \mathrm{c}$ & $39.20 \mathrm{~b}$ & $28.80 \mathrm{c}$ \\
Hydroalcoholic & $1.60 \mathrm{e}$ & $54.40 \mathrm{a}$ & $64.40 \mathrm{a}$ \\
Hexanenic & $53.60 \mathrm{~b}$ & $40.00 \mathrm{~b}$ & $28.40 \mathrm{c}$ \\
Chloroform & $58.00 \mathrm{~b}$ & $38.40 \mathrm{~b}$ & $30.80 \mathrm{c}$ \\
Water & $76.00 \mathrm{a}$ & $16.80 \mathrm{~d}$ & $22.40 \mathrm{~d}$ \\
Chemical nematicide & $16.40 \mathrm{~d}$ & $56.80 \mathrm{a}$ & $36.40 \mathrm{~b}$ \\
\hline CV (\%) & 10.14 & 7.34 & 9.47 \\
\hline
\end{tabular}

Means followed by the same letter within each column are not significantly different according to the Scott-Knott test at $5 \%$ probability.

\section{Experiment 2: Effect of crambe extracts dosage}

The hatching of $M$. incognita juveniles was lower in the hydroalcoholic and grinding extracts at a concentration of approximately $300 \mathrm{mg} \mathrm{L}^{-1}$ (Figure 1A). The inhibition of hatching at grinding extract concentrations of 200, 300, and $400 \mathrm{mg} \mathrm{L}^{-1}$ was approximately 40,46 , and 44 percentage points higher, respectively, when compared to the chemical nematicide treatment. For the hydroalcoholic extract, the hatching reduction was 49, 43, and 35 percentage points at doses of 200, 300, and $500 \mathrm{mg}$ $\mathrm{L}^{-1}$, respectively. The inhibition of juveniles hatching in the methanolic extract was $18,41,40$, and 37 percentage points lower at doses of 200, 300, 400, and $500 \mathrm{mg} \mathrm{L}^{-1}$, respectively, when compared to the chemical nematicide. No reduction of hatching was observed when increasing the dose of the extracts. The extract used has several different compounds belonging to the group of glucosinolates and it is possible that there is an antagonistic interaction between them, as a result of competition for target sites of these molecules in the nematode, or the inhibition of cellular capacitation of the nematotoxic molecule (MANDALARI et al., 2010). 
Figure 1. Hatching (A), mobility (B), and mortality (C) of Meloidogyne incognita juveniles in various doses of methanolic, hydroalcoholic, and grinding extracts of Crambe abyssinica leaves and the chemical nematicide Carbofuran. *Letters between the chemical treatment and each dose in each extract do not differ according to the Dunnett test at 5\% probability. Marechal Cândido Rondon, PR, 2013.
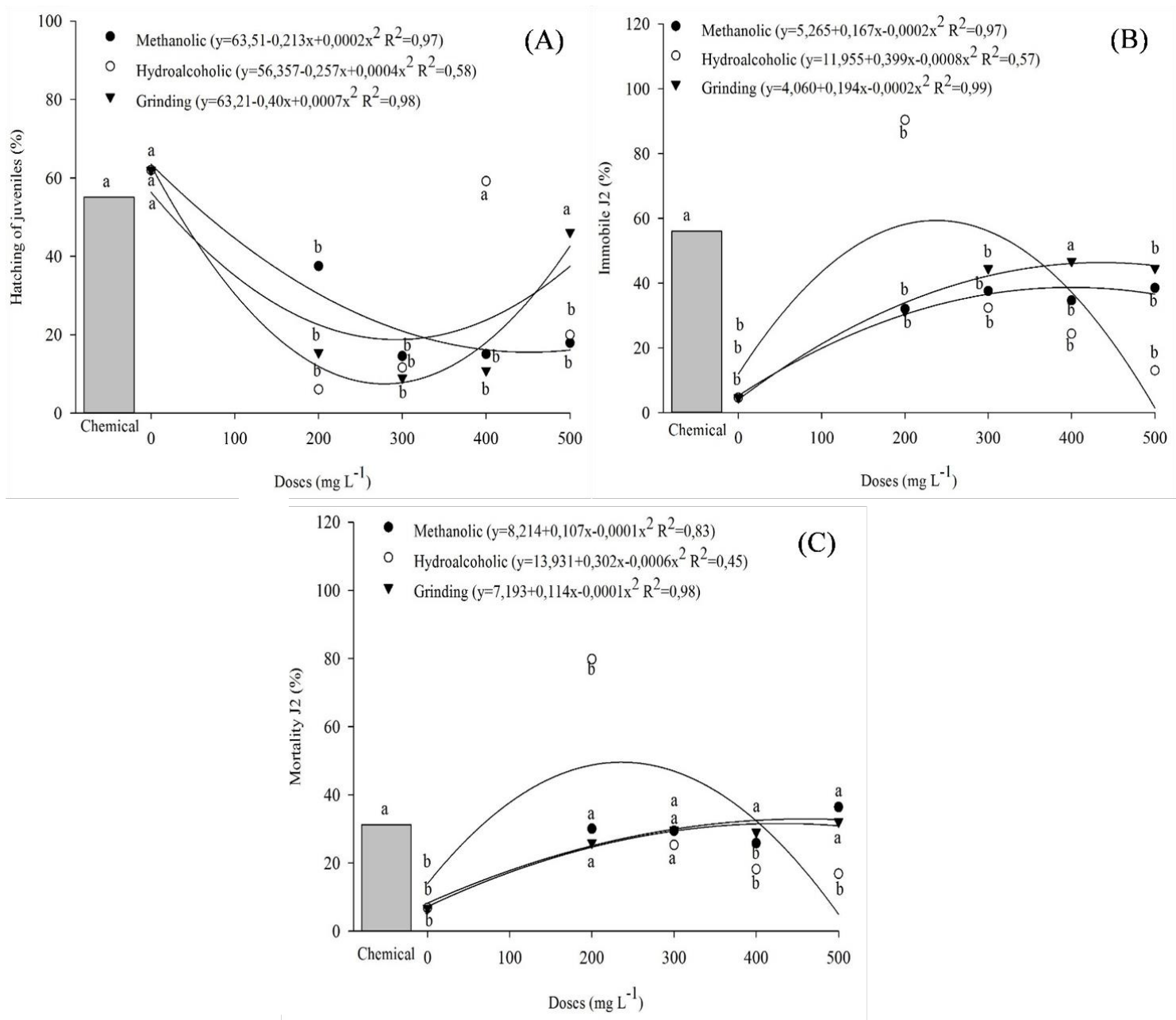

The greatest mobility inhibition was observed in the hydroalcoholic extract at a dose of $250 \mathrm{mg}$ $\mathrm{L}^{-1}$, with $62 \%$ of immobile juveniles, 57 percentage points higher than the zero dose (Figure 1B). Both methanolic extracts obtained by grinding showed a maximum calculated dose of $450 \mathrm{mg} \mathrm{L}^{-1}$ at 40 and $51 \%$ mobility inhibition, respectively. The hydroalcoholic and methanol extracts had a lower effect on mobility compared to the chemical nematicide, with the exception of the $200 \mathrm{mg} \mathrm{L}^{-1}$ dose of hydroalcoholic extract with a value of $\mathrm{J} 2$ estate 34 percentage points higher. As for the extract obtained by grinding, only the dose of $400 \mathrm{mg} \mathrm{L}^{-1}$ had similar results to the chemical treatment, and the remaining doses had a lower effect.

The highest mortality (52\%) was observed in the hydroalcoholic extract at the dose of $250 \mathrm{mg} \mathrm{L}^{-1}$. This was 45 percentage points greater than the zero dose and 15 and 13 percentage points higher than the methanolic and grinding extracts respectively, at a dose of $500 \mathrm{mg} \mathrm{L}^{-1}$ (Figure 1C). The hydroalcoholic extract at a concentration of $200 \mathrm{mg} \mathrm{L}^{-1}$ induced 48 
percentage points higher mortality compared to the chemical treatment, while the dose of $300 \mathrm{mg}$ $\mathrm{L}^{-1}$ did not differ statistically from the chemical treatment. The mortality induced by the rest of the doses was lower. The mortality of the $\mathrm{J} 2$ in the ethanol and grinding extracts was similar. All doses of methanolic extract obtained by grinding resulted in a similar mortality as in the chemical treatment, except for the dose of $400 \mathrm{mg} \mathrm{L}^{-1}$ of methanolic extract.

Costa et al. (2003) found that the hydroalcoholic extract of Artemisia vulgaris L. completely inhibited the hatching of Meloidogyne megadora J2 at concentrations of 50 and $100 \mathrm{mg} \mathrm{ml}^{-1}$ and exposure to $0.5 \mathrm{mg} \mathrm{mL}^{-1}$ of extract caused less inhibition of juvenile hatching, verifying the dose-dependent effect.

For $M$. javanica the hatching rate in the methanol extract obtained by grinding presented similar results and the smallest hatching rate was observed at the dose of $350 \mathrm{mg} \mathrm{L}^{-1}$. A higher hatching rate was observed at higher doses of the hydroalcoholic extract, and $22 \%$ of hatching was observed at the dose of $250 \mathrm{mg} \mathrm{L}^{-1}$ (Figure 2A). Compared to the chemical nematicide, inhibition of hatching at the doses of 300,400 , and $500 \mathrm{mg} \mathrm{L}^{-1}$ of extract obtained by trituration was $14.7,15.6$, and 12 percentage points higher, respectively, and no statistical difference was observed for the $200 \mathrm{mg}$ $\mathrm{L}^{-1}$ dose. The doses of methanol and hydroalcoholic extracts did not differ in their nematicide actions, with the exception of doses 0 and $400 \mathrm{mg} \mathrm{L}^{-1}$ of hydroalcoholic extract, which promoted hatching.

The greatest inhibition of mobility was caused by the hydroalcoholic extract at the dose of 250 $\mathrm{mgL}^{-1}$ with $82 \%$ of $M$. javanica $\mathrm{J} 2$ being immobile, 36 percentage points higher compared to the zero dose (Figure 2B). All doses of extracts were similar to the chemical nematicide, except the zero dose, with less immobile $\mathrm{J} 2$ and the dose of $200 \mathrm{mg} \mathrm{L}^{-1}$ of hydroalcoholic extract with 28 percentage points higher mobility inhibition compared to the chemical nematicide.

A higher mortality rate of $M$. javanica J2 was promoted by the hydroalcoholic extract (Figure 2C), with $78 \%$ mortality at a dose of $250 \mathrm{mg} \mathrm{L}^{-1}$, 38 percentage points higher than the zero dose and 6 percentage points higher than the dose of 400 $\mathrm{mg} \mathrm{L} \mathrm{L}^{-1}$ of the methanol extract. The $M$. javanica J2 mortality increases linearly with the dose of the extract obtained by grinding, demonstrating the dose-dependent effect with $74 \%$ for $500 \mathrm{mg}$ $\mathrm{L}^{-1}$ When comparing the extracts to the chemical nematicide, the dose of $200 \mathrm{mg} \mathrm{L}^{-1}$ hydroalcoholic extract showed a higher J2 mortality, with approximately 33 percentage points higher mortality than the chemical treatment. The dose of $300 \mathrm{mg}$ $\mathrm{L}^{-1}$ showed 13 percentage points higher mortality, whereas the other doses did not differ from the chemical treatment. The methanolic extract at a dose of $400 \mathrm{mg} \mathrm{L}^{-1}$ had 10 percentage points higher mortality than the chemical nematicide, while the other did not differ from this. The extract obtained by grinding, at the doses of 100 and $200 \mathrm{mg} \mathrm{L}^{-1}$ had lower mortality than the nematicide, and doses from $300 \mathrm{mg} \mathrm{L}^{-1}$ had higher mortality than this.

The dose-dependent effect of plant extracts has been shown in other studies such as that involving methanolic extract of $C$. cassia against P. bursaphelenchus xylophilus K. (NGUYEN et al., 2009), aqueous extracts and methanolic neem seed on $M$. javanica juveniles (SILVA et al., 2008), and Tagetes patula L. against M. incognita (FRANZENER et al., 2007). 
Figure 2. Hatching (A), mobility (B), and mortality (C) of Meloidogyne javanica juveniles in various doses of methanolic, hydroalcoholic, and grinding extracts of Crambe abyssinica leaves and the chemical nematicide Carbofuran. *Letters between the chemical treatment and each dose in each extract do not differ according to the Dunnett test at 5\% probability. Marechal Cândido Rondon, PR, 2013.
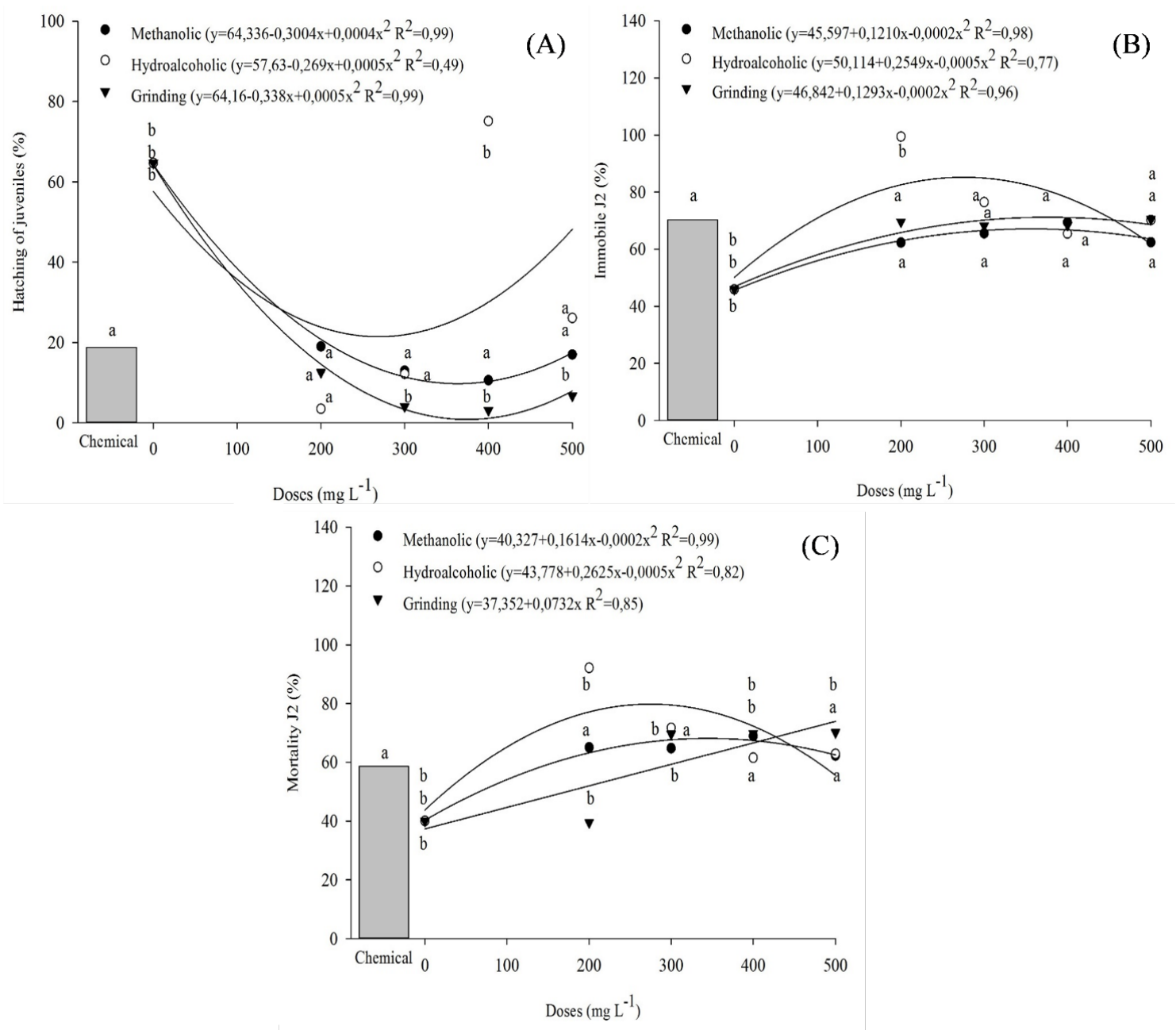

Experiment 3: Quantification and identification of isothiocyanate in crambe extracts

The methanolic and hydroalcoholic extracts were the ones with interactions with the molecules of the allyl isothiocyanate, with methanol being the most efficient solvent for extraction, at a concentration of $133.88 \mathrm{mg} \mathrm{L}^{-1}$ (Figure 3C). The hydroalcoholic solvent, despite the presence of allyl isothiocyanate at a concentration of 13.57

$m g \mathrm{~L}^{-1}$ was not significantly different from other extracts that had no affinity for the extraction of the allyl isothiocyanate. However, owing to the high polarity of the hydroalcoholic extract, it is possible that the solvent can be used for the extraction of other compounds with nematicidal effect. The types of solvents and their polarities can affect the concentration of the extracted compounds, because they influence the transfer of electrons and hydrogen atoms (SANTOS et al., 2012). 
Figure 3. Chromatogram of the concentration of allyl isothiocyanate in the hydroalcoholic (A) and methanol (B) extracts of Crambe abyssinica leaves. (C) Concentration of allyl isothiocyanate in each solvent. *Concentrations followed by the same letter in the column do not differ according to the Tukey test at $5 \%$ probability. Marechal Cândido Rondon, PR, 2013.
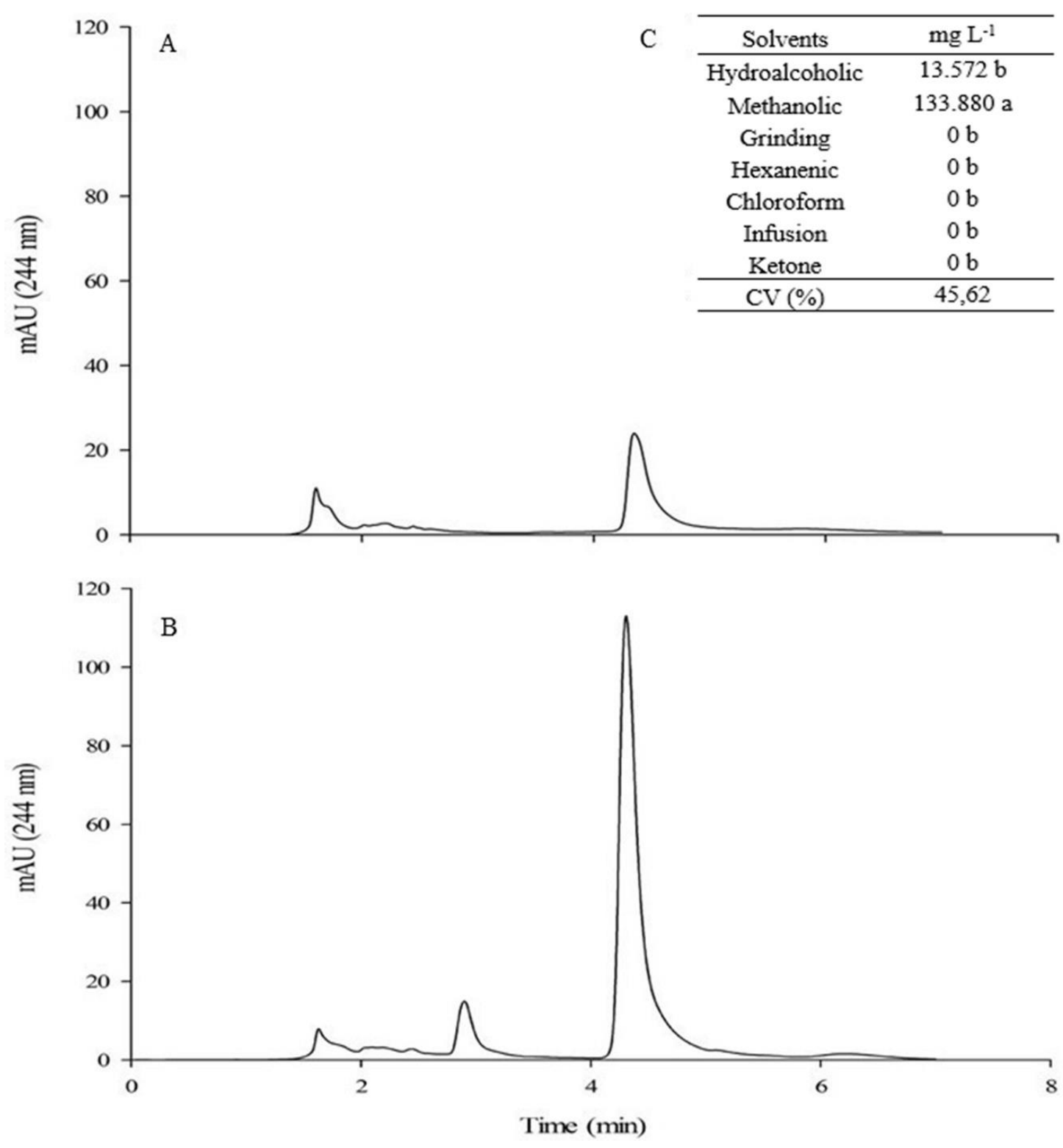

Some isothiocyanates such as benzyl benzyl thiocyanate, 1-phenylethyl isothiocyanate, isothiocyanate, methyl isothiocyanate, and phenyl and 2-phenylethyl isothiocyanate. However, isothiocyanate have been extracted from brassica acryloyl isothiocyanate and allyl isothiocyanate species and showed nematicidal effects (AISSANI et were the ones with the highest effect against al., 2013). Other isothiocyanates also showed some nematodes (WU et al., 2011). Glucosinolates and nematicide effects, such as ethyl isothiocyanate, their derivatives, such as isothiocyanates, isolated 
from various brassica species differ in their toxicity against nematodes. Species containing benzyl or 2-phenylethyl and smaller level allyl isothiocyanate were more effective against Tylenchulus semipenetrans C. and M. javanica q when compared to butyl, ethyl, methyl, phenyl, and 4-methylsulfinyl isothiocyanate (ZASADA; FERRIS, 2003). Glucosinolates were isolated and quantified from several species of brassica, as sinigrin from Brassica juncea L., progoitrin from $B$. napus N., epi-progoitrin from Crambe abyssinica, glucosinalbin from Sinapis alba L., glucotropaeolin from Lepidium sativum L., and glucoraphanin from Raphanus sativus L. (FINIGUERRA et al., 2001).

In a complementary way, the main glucosinate of C. abyssinica 'Belenzian' is epi-progoitrin whose activity is attributed to the chemical reactivity of the isothiocyanate groups, which can easily react with proteins (LEONI et al., 1997). Glucosinolate derivatives of $B$. napus extract were identified and HPLC analysis showed the presence of progoitrin, epi-progoitrin, and sinigrin (LAZZERI et al., 1993).

Given that only the methanolic and hydroalcoholic extracts presented allyl isothiocyanate, the nematicide and nematostatic effects of these and other extracts tested in this work cannot be attributed only to the presence of this compound, suggesting that other molecules with an effect on nematodes are present in C. abyssinica leaves, thus instigating, further studies for their identification.

\section{Conclusions}

The hydroalcoholic extract has a higher inhibitory effect on hatching, and a higher nematostatic and nematicide effect against $M$. incognita and $M$. javanica, followed by methanolic extract and extract from grinding.

The hydroalcoholic extract at a dose of $250 \mathrm{mg}$ $\mathrm{L}^{-1}$ showed greater effect on mortality and inhibition of mobility and hatching of $M$. incognita and $M$. javanica.
Only the methanolic and hydroalcoholic extracts presented allyl isothiocyanate.

\section{Acknowledgments}

The authors thank Dr. Éder Lisandro de Moraes Flores for permitting the use and assisting with the HPLC analysis in UTFPR. The authors also thank CAPES for the first author's doctoral fellowship, the Araucaria Support Foundation for Scientific and Technological Development of Paraná, affiliated to the State Secretariat of Science, Technology and Higher Education - SETI, as well as the productivity grant OJK research, and CNPq, for the financial support and productivity grant JRS research and ACGJ.

\section{References}

ADEGBITE, A. A.; ADESIYAN, S. O. Root extracts of plants to control root-knot nematode on edible soybean. World Journal of Agricultural Sciences, Faisalabad, v. 1, n. 1, p. 18-21, 2005.

AISSANI, N.; TEDESCHI, P.; MAIETTI, A.; BRANDOLINI, V.; GARAU, V. L.; CABONI, P. Nematicidal activity of allylisothiocyanate from horseradish (Armoracia rusticana) roots against Meloidogyne incognita. Journal of Agricultural and Food Chemistry, Washington, v. 61, n. 20, p. 4723-4727, 2013.

AMARAL, D. R.; OLIVEIRA, D. F.; CAMPOS, V. P.; CARVALHO, D. A. Efeito de alguns extratos vegetais na eclosão, mobilidade, mortalidade e patogenicidade de Meloidogyne exigua do cafeeiro. Nematologia Brasileira, Piracicaba, v. 26, n. 1, p. 43-48, 2002.

ATKINSON, H. J.; LILLEY, C. J.; URWIN, P. E. Strategies for transgenic nematode control in developed and developing world crops. Current Opinion in Biotechnology, London, v. 23, n. 2, p. 251-256, 2012.

BONETI, J. I. S.; FERRAZ, S. Modificação do método de Hussey e Barker para a extração de ovos de Meloidogyne exigua em raízes de cafeeiro. Fitopatologia Brasileira, Brasília, v. 6, n. 3, p. 553, 1981

CABONI, P.; SABA, M.; TOCCO, G.; CASU, L.; MURGIA, A.; MAXIA, A.; MENKISSOGLUSPIROUDI, U. E.; NTALLI, N. Nematicidal activity of mint aqueous extracts against the root-knot nematode 
Meloidogyne incognita. Journal of Agricultural and Food Chemistry, Washington, v. 61, n. 41, p. 9784-9788, 2013.

CLARKE, D. B. Glucosinolates, structures and analysis in food. Analytical Methods: Advancing Methods and Applications, Cambridge, v. 2, n. 4, p. 310-325, 2010.

COSTA, M. C. C. D.; AGUIAR, J. S.; NASCIMENTO, S. C. Atividade citotóxica de extratos brutos de Lippia alba (Mill.) N.E. Brown (Verbenaceae). Acta Farmaceutica Bonaerense, Buenos Aires, v. 23, n. 3, p. 349-352, 2004.

COSTA, M. J. N.; CAMPOS, V. P.; PFENNING, L. H.; OLIVEIRA, D. F. Toxicidade de filtrados fúngicos a Meloidogyne incognita. Fitopatologia Brasileira, Brasília, v. 26, n. 4, p. 749-755, 2001.

COSTA, S. S. R.; SANTOS, M. S. N. A.; RYAN, M. F. Effect of Artemisia vulgaris rhizome extracts on hatching, mortality, and plant infectivity of Meloidogyne megadora. Journal of Nematology, Hanover, v. 35, n. 4, p. 437-442, 2003.

CRUZ, C. D. Programa Genes: biometria. Viçosa, MG: UFV, 2006. 382 p.

DAUBOS, P.; GRUMEL, V.; IORI, R.; LEONI, O.; PALMIERI, S.; ROLLIN, P. Crambe abyssinica meal as starting material for the production of enantiomerically pure fine chemicals. Industrial Crops and Products, Amsterdam, v. 7, n. 2, p. 187-193, 1998.

ELBADRI, G. A.; LEE, D. W.; PARK, J. C.; YU, H. B.; $\mathrm{CHOO}, \mathrm{H}$. Y. Evaluation of various plant extracts for their nematicidal efficacies against juveniles of Meloidogyne incognita. Journal of Asia-Pacific Entomology, Suwon, v. 11, n. 2, p. 99-102, 2008.

FALASCA, S. L.; FLORES, N.; LAMAS, M. C.; CARBALLO, S. M.; ANSCHAU, A. Crambe abyssinica: An almost unknown crop with a promissory future to produce biodiesel in Argentina. International Journal of Hydrogen Energy, Oxford, v. 35, n. 11, p. 5808-5812, 2010.

FERRAZ, L. C. C. B.; MONTEIRO, A. R. Nematoides. In: AMORIM, L.; RESENDE, J. A. M.; BERGAMIM FILHO, A. Manual de fitopatologia: princípios e conceitos. 4. ed. São Paulo: Agronômica Ceres, 2011. cap. 13, p. 277-305.

FINIGUERRA, M. G.; IORI, R.; PALMIERI, S. Soluble and total myrosinase activity in defatted Crambe abyssinica Meal. Journal of Agriculture and Food Chemistry, Washington, v. 49, n. 2, p. 840-845, 2001.

FRANZENER, G.; FRANZENER, A. S. M.; STANGARLIN, J. R.; FURLANETTO, C.; SCHWANESTRADA, K. R. F. Proteção de tomateiro a Meloidogyne incognita pelo extrato de Tagetes patula. Nematologia Brasileira, Piracicaba, v. 31, n. 1, p. 27-36, 2007.

FRANZENER, G.; UNFRIED, J. R.; STANGARLIN, J. R.; FURLANETTO, C. Nematoides formadores de galha e de cisto patogênicos à cultura da soja em municípios do oeste do Paraná. Nematologia Brasileira, Piracicaba, v. 29, n. 2, p. 261-265, 2005.

HARTMAN, K. M.; SASSER, J. N. Identification of Meloidogyne species on the basis of differential host test and perineal pattern morphology. In: BARKER, K. R.; CARTER, C. C.; SASSER, J. N. An advanced treatise on Meloidogyne. North Carolina: Methodology, 1985. p. 69-77.

HERZALLAH, S.; HOLLEY, R. Determination of sinigrin, sinalbin, allyl- and benzyl isothiocyanates by RP-HPLC in mustard powder extracts. Food Science and Technology, Campinas, v. 47, n. 2, p. 193-299, 2012.

JACKSON, S. J. T.; SINGLETARY, K. W. Sulforaphane: a naturally occurring mammary carcinoma mitotic inhibitor, which disrupts tubulin polymerization. Carcinogenesis, Oxford, v. 25, n. 2, p. 219-227, 2004.

LAZZERI, L.; TACCONI, R.; PALMIERI, S. In vitro activity of some glucosinolates and their reaction products toward a population of the nematode Heteroders schachtii. Journal of Agricultural and Food Chemistry, Washington, v. 41, n. 5, p. 825-629, 1993.

LEONI, O.; IORI, R.; PALMIERI, E. E.; MENEGATTI, E.; CORTESI, R.; NASTRUZZI, C. Myrosinasegenerated isothiocyanate from glucosinolates: isolation, characterization and in vitro antiproliferative studies. Bioorganic \& Medicinal Chemistry, Califórnia, v. 5, n. 9, p. 1799-1806, 1997.

LOGUERCIO, A. P.; BATTISTIN, A.; VARGAS, A. C.; HENZEL, A.; WITT, N. M. Atividade antibacteriana de extrato hidro-alcoólico de folhas de jambolão (Syzygium cumini_(L.) Skells). Ciência Rural, Santa Maria, v. 35, n. 2, p. 371-376, 2005.

MANDALARI, G. C.; BISIGNANO, C.; D'ARRIGO, M.; GINESTRA, G.; ARENA, A.; TOMAINO, A.; WICKHAM, M. S. J. Antimicrobial potential of polyphenols extracted from almond skins. Letters in Applied Microbiology, Oxford, v. 51, n. 1, p. 83-89, 2010.

MI, L.; XIAO, Z.; HOOD, B. L.; DAKSHANAMURTHY, S.; WANG, X.; GOVIND, S.; CONRADS, T. P.; VEENSTRA, T. D.; CHUNG, F. L. Covalent binding to tubulin by isothiocyanates: a mechanism of cell growth arrest and apoptosis. The Journal of Biological Chemistry, Baltimore, v. 283, n. 32, p. 22136-22146, 2008. 
MOHN, T.; CUTTING, B.; ERNEST, B.; HAMBURGER, M. Extraction and analysis of intact glucosinolates a validated pressurized liquid extraction/liquid chromatography-mass spectrometry protocol for Isatis tinctoria, and qualitative analysis of other cruciferous plants. Journal of Chromatography, Flórida, v. 1166, n. 1, p. 142-151, 2007.

MURATA, M.; YAMASHITA, N.; INOUE, S.; KAWANISHI, S. Mechanism of oxidative DNA damage induced by carcinogenic allyl isothiocyanate. Free Radical Biology \& Medicine, New York, v. 28, n. 5, p. 797-805, 2000.

NEVES, W. S.; FREITAS, L. G.; COUTINHO, M. M.; DALLEMOLE-GIARETTA, R.; FABRY, C. F. S.; DHINGRA, O. D.; FERRAZ, S. Ação nematicida de extratos de alho, mostarda, pimenta malagueta, de óleo de mostarda e de dois produtos à base de capsainóides e alil isotiocianato sobre juvenis de Meloidogyne javanica, (Treub) Chitwood, 1949, em casa de vegetação. Summa Phytopathologica, Botucatu, v. 35, n. 4, p. 255-261, 2009.

NGUYEN, D. M. C.; NGUYEN, V. N.; SEO, D. J.; PARK, R. D.; JUNG, W. J. Nematicidal activity of compounds extracted from medicinal plants against the pine wood nematode Bursaphelenchus xylophilus. Nematology, Leiden v. 11, n. 6, p. 835-845, 2009.

SANTOS, M. S.; MIGUEL, O. G.; PETKOWICZ, C. L. O.; CÂNDIDO, L. M. B. Potencial antioxidante e perfil dos ácidos graxos de sementes de gabiroba (Campomanesisa xanthocarpa Berg). Ciência e Tecnologia de Alimentos, Campinas, v. 32, n. 2, p. 234-238, 2012.
SILVA, J. C. T.; OLIVEIRA, R. D. L.; JHAM, G. N.; AGUIAR, N. D. C. Effect of neem seed extracts on the development of the Soybean Cysts Nematode. Tropical Plant Pathology, Viçosa, MG, v. 33, n. 3, p. 171-179, 2008.

STANGARLIN, J. R.; KUHN, O. J.; ASSI, L.; SCHWAN-ESTRADA, K. R. F. Control of plant diseases using extracts from medicinal plants and fungi. In: MÉNDEZ-VILAS, A. (Ed.). Science against microbial pathogens. Badajoz: Communicating Current Research and Technological Advances, 2011. p. 1033-1042.

WU, H.; WANG, C. J.; BIAN, X. W.; ZENG, S. Y.; LIN, K. C.; WU, B.; ZHANG, G. A.; ZHANG, X. Nematicidal efficacy of isothiocyanates against root-knot nematode Meloidogyne javanica in cucumber. Crop Protection, Amsterdam, v. 30, n. 1, p. 33-37, 2011.

WU, H.; ZHANG, G. A.; ZENG, S.; KAI-CHUN, L. Extraction of allyl isothiocyanate from horseradish (Armoracia rusticana) and its fumigant insecticidal activity on four stored-product pests of paddy. Pest Management Science, Sussex, v. 65, n. 9, p. 1003-1008, 2009.

ZASADA, I. A.; FERRIS, H. Sensitivity of Meloidogyne javanica and Tylenchulus semipenetrans to isothiocyanates in laboratory assays. Nematology, Leiden, v. 93, n. 6, p. 747-750, 2003. 
